\title{
WHEN THERE'S ONLY DUST LEFT
}

\section{They aimed for the head.}

\section{BY JEREMY SZAL}

$\mathrm{I}$ tried to kill myself on the sixteenth day of living in the facility. I grabbed the knife they'd made the mistake of giving me for food, peeled back my skinsuit and sliced both my wrists open, watching the crimson blossom like bloody flowers in fast-forward.

They caught me before I bled out. The guards held me down as Dr Jolkivo pumped me full of medjel and sprayed my wounds with biofoam. "It's okay," she whispered as I lay shaking, my last happy memory dancing through my mind. "We'll get it out. We'll find a way."

I fought a war for them and still they would not let me die.

Instead of strapping me in full-body restraints again, they put me in a new room. A change of scenery might do me good, Dr Jolkivo suggested. I knew it wouldn't make a bit of difference.

"Tried to leave?" the Duster sneered from the back of my skull as I sat on the bench. A sinister, androgynous voice sucked dry of warmth. "You don't get to go that easily."

"Shut up," I whispered. "Just leave me alone."

Mistake. The AI just laughed. "Oh, Buikov, you know that's not how it works."

Our first error had been to assume that the enemy would mount their assault with conventional weapons. Instead they released nanoswarms of AIs into the air as dust particles. The wind did the rest and within days half our army had enemy AIs installed in their heads. Programmed to hate us, despise us, torment us. Telling us things, showing us things that weren't real. A good chunk of our soldiers went insane and died. But I was still around.

Lucky me.

"They're never getting rid of us," the Duster purred. I looked away, as if it would help. "You're never going to see Kim again."

My muscles tightened like bridge cables. "How do you know about her?"

"You were thinking about me," came Kim's silky voice, which had always soothed me. "Your last happy memory. You gave me access to her. And your final moments together."

I squeezed my palms to my temples. "Leave her out of this!"
"Dwelling on her only makes it worse," the Duster said, voice back to normal. "We read your brain synapses. Your neurotransmitters - all your memories and emotions and body responses - they're just fuel." A gurgle bubbled across my cranium something akin to laughter. "The longer you think about it, the more you give me to play with."

"Go to hell!" I screamed, tendrils of terror squirming inside me. "Just stop, just - "

My heart rose to my throat. The cell walls had vanished and I was staring at the golden curve of a beach. Wind caressed my sweatslick skin, waves crashing on the shore. Kim stood smiling on the sand, red hair flapping in the breeze.

"Come," she whispered, beckoning to me.

"How are you doing this?" I was shaking now, my chest constricted as the image of our last day before I left for the war evaporated.

"The longer I stay in your head, the deeper the roots grow," taunted the Duster. "Want to see?" The room took on a tundra chill and forests materialized around me. Snow dusted the ground. I was seeing my squad trek through the Ural Mountains. I watched as my friend Mikhail slipped on a ledge and toppled to his death, screams echoing in my brain.

I stepped back, shaking as my memories unspooled in front of me. His screaming got $\rightarrow$ NATURE.COM

Follow Futures: @NatureFutures

$f$ go.nature.com/mtoodm louder and louder, snow falling on my shoulders as I told myself it wasn't real, none of it was real. It was just the Duster toying with my head.

"Stop it!" I roared, gripping my head with my hands. "Leave me alone! Please!"

"We can even change who you are," the Duster said. Through tear-smeared vision I saw myself in the mirror. My Slavic features melted away and I was staring back at a blonde-haired Nordic, then a slim, high-cheek-boned Afro-Caribbean, fading into a potbellied east Asian man. "Enough!" I screamed, clutching at my now black hair. "Enough, you botched abortion of a -"

The image curdled and I was now a woman. I was growing older

by the second, wrinkles appearing in my skin. "You don't even know what you are, do you?" the Duster taunted.

"Stop!"

"You're nobody." My body started to fade; as if I was being smeared away. "You don't exist."

I screamed, throat like sandpaper as I smashed my head against the glass. The world swam. The mirror starred into a spider's web and a shard of glass toppled to the floor. Panting, I scooped it up, dug it into the meat of my wrist and raked it down to the elbow joint, scraping against the bone as my skin sheared apart, exposing the gory network of veins, muscles and arteries. Hot, glossy blood fountained out, my arm ablaze with pain. I dropped to the floor in agony, waiting for the end to swallow me up.

"Do you really think they'd give you a mirror?" I glanced up. There was nothing on the wall, only a dent from my forehead. My arm was undamaged, the floor unbloodied and free of glass. "I told you, you don't get to escape that easily."

I spun into a frenzy, clawing at my wrists, trying to slice them open with my nails. The rage abated and I sank sobbing to the floor as laughter and the brine of the beach swirled around me. Cool waves lapped at my feet, Kim's breath hot on my neck as she kept calling for me to come and feel the sand between my toes.

Jeremy Szal's work has appeared in Nature, Abyss \& Apex, Lightspeed and others. He lives in Sydney, Australia, and seeks literary representation. Find him at jeremyszal.com or@jeremyszal 